Published in final edited form as:

J Am Chem Soc. 2019 April 03; 141(13): 5504-5510. doi:10.1021/jacs.9b00242.

\title{
The Reduction Potentials of P450 Compounds I and II: Insight into the Thermodynamics of C-H Bond Activation.
}

\author{
Kaustuv Mittra, Michael T. Green \\ Department of Chemistry, University of California, Irvine, California, 92697 \\ Department of Molecular Biology and Biochemistry, University of California, Irvine. California, \\ 92697
}

\begin{abstract}
We present a mixed experimental/theoretical determination of the bond strengths and redox potentials that define the ground state thermodynamics for $\mathrm{C}-\mathrm{H}$ bond activation in cytochrome P450 catalysis. Using redox titrations with $\left[\operatorname{Ir}(\mathrm{IV}) \mathrm{Cl}_{6}\right]^{2-}$ we have determined the compound II/ ferric (or $\mathrm{Fe}(\mathrm{IV}) \mathrm{OH} / \mathrm{Fe}(\mathrm{III}) \mathrm{OH}_{2}$ ) couple and its associated $\mathrm{D}(\mathrm{O}-\mathrm{H})_{\text {Ferric }}$ bond strength in CYP158. Knowledge of this potential as well as the compound II/ferric (or $\mathrm{Fe}(\mathrm{IV}) \mathrm{O} / \mathrm{Fe}(\mathrm{III}) \mathrm{OH}$ ) reduction potential in horseradish peroxidase and the two-electron compound I/ferric (or $\mathrm{Fe}(\mathrm{IV}) \mathrm{O}\left(\mathrm{Por}^{\circ}\right) /$ $\left.\mathrm{Fe}(\mathrm{III}) \mathrm{OH}_{2}(\mathrm{Por})\right)$ reduction potential in aromatic peroxidase has allowed us to gauge the accuracy of theoretically determined bond strengths. Using the restricted open shell (ROS) method as proposed by Wright and coworkers, we have obtained $\mathrm{O}-\mathrm{H}$ bond strengths and associated redox potentials for charge-neutral $\mathrm{H}$-atom-reductions of these iron(IV)-hydroxo and -oxo porphyrin species that are within $1 \mathrm{kcal} / \mathrm{mol}$ of experimentally determined values, suggesting that the ROS method may provide accurate values for the P450-II O-H bond strength and P450-I reduction potential. The efforts detailed here indicate the ground state thermodynamics of $\mathrm{C}-\mathrm{H}$ bond activation in $\mathrm{P} 450$ are best described as follows: $\mathrm{E}^{0}{ }^{\prime}$ Comp-I $=1.22 \mathrm{~V}$ (at pH 7, vs. NHE) with $\mathrm{D}(\mathrm{O}-$ $\mathrm{H})_{\text {Comp-II }}=95 \mathrm{kcal} / \mathrm{mol}$, and $\mathrm{E}^{0}$ ' Comp-II $=0.99 \mathrm{~V}\left(\right.$ at $\mathrm{pH} 7$, vs. NHE) with $\mathrm{D}(\mathrm{O}-\mathrm{H})_{\text {Ferric }}=90 \mathrm{kcal} /$ mol.
\end{abstract}

\section{Graphical Abstract}

*Corresponding Author m.green@uci.edu.

Supporting Information. Determination of pseudo-equilibrium concentrations and the $\left[\left[\mathrm{Ir}(\mathrm{III}) \mathrm{Cl}_{6}\right]^{3-}\right] /[\mathrm{CYP} 158-\mathrm{II}]$ ratio for a representative stopped-flow reaction. Mössbauer data for a P450-II sample prepared by the reaction of ferric enzyme with $\left[\mathrm{Ir}(\mathrm{IV}) \mathrm{Cl}_{6}\right]^{2-}$. Electrochemical methods and data for the $\left[\mathrm{Ir}(\mathrm{IV}) \mathrm{Cl}_{6}\right]^{2-} /\left[\mathrm{Ir}(\mathrm{III}) \mathrm{Cl}_{6}\right]^{3-}$ couple. 


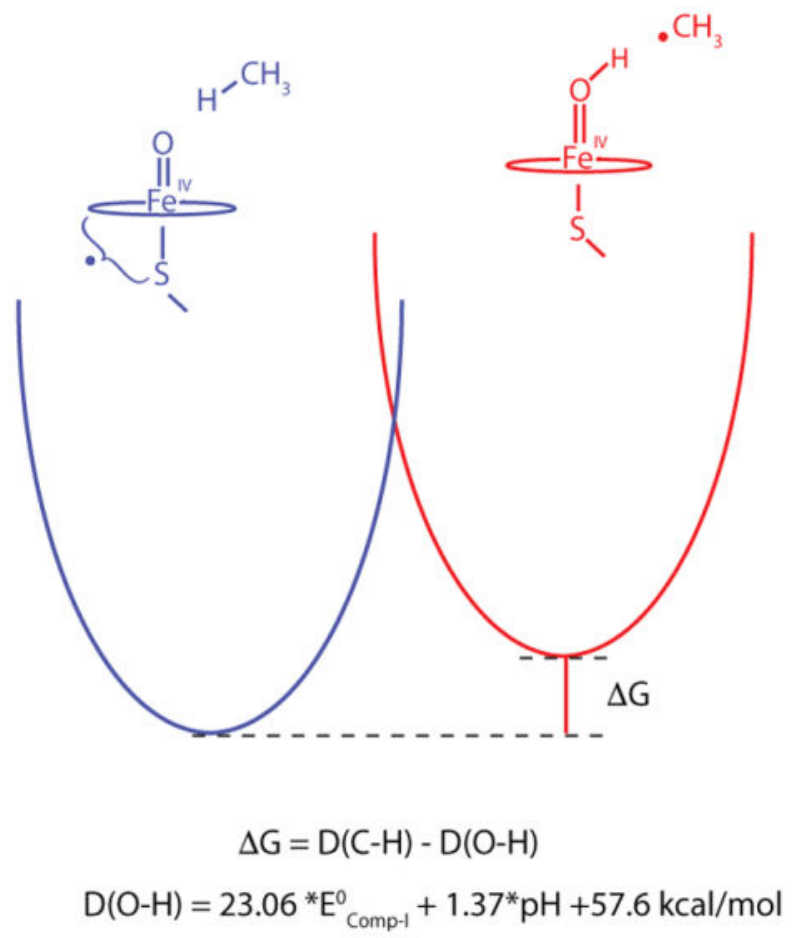

\section{INTRODUCTION}

The controlled activation of inert $\mathrm{C}-\mathrm{H}$ bonds remains one of the grand challenges of synthetic chemistry. ${ }^{1}$ In an effort to further our understanding of this important class of transformations, we have sought to examine fundamental aspects of $\mathrm{C}-\mathrm{H}$ bond activation in cytochrome $\mathrm{P} 450$ (P450) catalysis. ${ }^{2-5} \mathrm{P} 450$ s are a class of thiolate-ligated heme proteins that excel at $\mathrm{C}-\mathrm{H}$ bond activation. ${ }^{6}$ These enzymes utilize molecular oxygen and the formal equivalents of dihydrogen $\left(2 \mathrm{H}^{+}+2 \mathrm{e}^{-}\right)$to catalyze the oxidation of a broad range of biomolecules. ${ }^{6-9}$ The principal intermediates in these reactions are a pair of high-valent iron-oxo and ironhydroxo species called compounds I and II. ${ }^{4,5}$ Although recent electronic and structural characterizations of these reactive intermediates have provided significant insight into metal-oxo mediated $\mathrm{C}-\mathrm{H}$ bond activation, important questions remain.

There is currently a debate in the field about the importance of ground state thermodynamics in metal-oxo driven $\mathrm{C}-\mathrm{H}$ bond activation. The debate centers on whether ground state thermodynamics play the dominant role in determining reactivity or whether some other property of the system (e.g. oxyl-radical character, metal-oxo basicity, metal-oxo spin state, width of the activation barrier, or multi-state reactivity) can provide an intrinsic lowering of the activation barrier. ${ }^{10-19}$ The examination of this fundamental issue has been hindered not only by the difficulty of quantifying these properties for highly-reactive high-valent species but also by the lack of a series of isoelectronic and isostructural compounds over which these properties can be varied.

Ground state thermodynamics, in the form of Linear Free Energy Relationships (LFER), have often been used to explain metal-oxo mediated C-H bond activation. ${ }^{20-22}$ From this 
viewpoint, $\mathrm{P} 450$ reactivity can be understood in terms of the strength of the $\mathrm{O}-\mathrm{H}$ bond formed during $\mathrm{H}$-atom abstraction. ${ }^{5}$ Figure 1 shows $\mathrm{D}(\mathrm{O}-\mathrm{H})_{\text {Comp-II }}$, the homolytic bonddissociation free energy of the iron(IV)hydroxide center in $\mathrm{P} 450$ compound II (P450-II). Within the LFER framework, this is the key parameter that determines the reactivity of compound I towards $\mathrm{C}-\mathrm{H}$ bonds. Fig. 1 also shows $\mathrm{D}(\mathrm{O}-\mathrm{H})_{\text {Ferric }}$ of the ferric water-bound heme. P450s have been found to perform desaturation and carbon-carbon bond cleaving reactions, in which $\mathrm{P} 450-\mathrm{II}$ oxidizes the substrate a second time. ${ }^{23-29}$ These oxidations involve either direct $\mathrm{H}$-atom abstraction or a proton-coupled oxidation of the substrate radical to generate the ferric water-bound form of the enzyme. In a similar fashion, one expects the non-rebound reactivity of $\mathrm{P} 450-\mathrm{II}$ towards hydrocarbons to be dictated by $\mathrm{D}(\mathrm{O}$ $\mathrm{H})_{\text {Ferric }}$. In principle, both of these bond strengths could be determined from the reduction potentials of P450-I ( $\mathrm{E}^{0^{\prime}}$ Comp-I $)$ and P450-II ( $\mathrm{E}^{0^{\prime}}$ Comp-II $)$, using equations 1 and 2 shown in the methods section. However, to date, neither of these quantities has been reported.

Herein we present a mixed experimental/theoretical determination of the bond strengths and redox potentials that define the ground state thermodynamics for $\mathrm{C}-\mathrm{H}$ bond activation in $\mathrm{P} 450$ catalysis. Although the highly reactive nature of $\mathrm{P} 450-\mathrm{I}$ presents a significant obstacle to the experimental determination of the P450-I/P450-II redox couple, we have found that the $\mathrm{P} 450-\mathrm{II} /$ ferric couple is amenable to redox titrations with $\left[\operatorname{Ir}(\mathrm{IV}) \mathrm{Cl}_{6}\right]^{2-}$. Knowledge of this potential as well as the compound II/ferric (or $\mathrm{Fe}(\mathrm{IV}) \mathrm{O} / \mathrm{Fe}(\mathrm{III}) \mathrm{OH}$ ) reduction potential in horseradish peroxidase ${ }^{30}$ and the two-electron compound $\mathrm{I} /$ ferric (or $\mathrm{Fe}(\mathrm{IV}) \mathrm{O}\left(\right.$ Por $^{\circ}$ )/ $\mathrm{Fe}(\mathrm{III}) \mathrm{OH}_{2}$ (Por)) reduction potential in aromatic peroxidase ${ }^{31}$ has allowed us to gauge the accuracy of theoretically determined bond strengths. Using the restricted open shell (ROS) method as proposed by Wright and coworkers ${ }^{32}$, we have obtained $\mathrm{O}-\mathrm{H}$ bond strengths associated with the charge-neutral $\mathrm{H}$-atom-reductions of iron(IV)-oxo and -hydroxo porphyrin species that are within $1 \mathrm{kcal} / \mathrm{mol}$ of the values obtained from the experimentally determined potentials, suggesting that the ROS method may provide accurate values for $\mathrm{D}(\mathrm{O}-\mathrm{H})_{\text {Comp-II }}$ and the $\mathrm{P} 450$-I reduction potential. We detail these results below.

\section{RESULTS}

\section{Experimental Determination of the P450 Compound II/Ferric potential}

Using methods similar to those employed by Hayashi and Yamazaki in their experiments on horseradish peroxidase $\mathrm{e}^{30}$, the reduction potential of P450-II was determined by monitoring the stopped-flow reaction of $\left[\mathrm{Ir}(\mathrm{IV}) \mathrm{Cl}_{6}\right]^{2-}$ with ferric CYP158. ${ }^{33,34}$ This isoform of P450 was chosen because CYP158-II can be generated in very high yield ( 100\%, Figure S2) and the intermediate is relatively stable over a wide $\mathrm{pH}$ range. ${ }^{5}$ Three phases of the reaction of ferric CYP158 with $\left[\mathrm{Ir}(\mathrm{IV}) \mathrm{Cl}_{6}\right]^{2-}$ can be seen in Figure 2, which shows the absorbance at $430 \mathrm{~nm}$ as a function of time. Initially, there is rapid formation of compound II as $\left[\operatorname{Ir}(\mathrm{IV}) \mathrm{Cl}_{6}\right]^{2-}$ oxidizes ferric enzyme. This rapid formation is followed by a period of pseudo-equilibrium where there is very little change in the concentrations of the reactive species. Finally there is a region of decay as both the $\left[\mathrm{Ir}(\mathrm{IV}) \mathrm{Cl}_{6}\right]^{2-}$ and CYP158-II concentrations decrease. During this final phase, CYP158-II decays to ferric enzyme, which can be reoxidized, but as the reaction proceeds and $\left[\mathrm{Ir}(\mathrm{IV}) \mathrm{Cl}_{6}\right]^{2-}$ is consumed there is less 
driving force for compound II formation. Additionally, there is a small, but not insignificant, ( $6 \%$ on average) decay of $\left[\operatorname{Ir}(\mathrm{IV}) \mathrm{Cl}_{6}\right]^{2-}$ due to hydrolysis. ${ }^{35}$

The reduction potential of CYP158-II was obtained from the Nernst equation using concentrations of reactive species in the pseudo-equilibrium phase (Phase II, Figure 2). For each stopped-flow reaction, several time points in this region (generally four but not less than three) were selected (see Supporting Information for details). For each of these points, the experimental UV/visible spectrum $(300-700 \mathrm{~nm})$ was simulated using the known spectra of ferric CYP158, CYP158-II, and $\left[\mathrm{Ir}(\mathrm{IV}) \mathrm{Cl}_{6}\right]^{2-}$ to obtain the concentrations of these species (Figure 3). Given that the extinction coefficient of $\left[\mathrm{Ir}(\mathrm{III}) \mathrm{Cl}_{6}\right]^{3-}$ is significantly less (see methods) than those of the other species in the reaction, it was not possible to determine the concentration of the $\operatorname{Ir}(\mathrm{III})$ complex directly from simulations of the UV/visible spectra. For our calculations of the reduction potential, the concentration of $\left[\mathrm{Ir}(\mathrm{III}) \mathrm{Cl}_{6}\right]^{3-}$ was set equal to the amount $\left[\operatorname{Ir}(\mathrm{IV}) \mathrm{Cl}_{6}\right]^{2-}$ consumed, minus losses of $\left[\mathrm{Ir}(\mathrm{IV}) \mathrm{Cl}_{6}\right]^{2-}$ due to hydrolysis. The losses due to hydrolysis were determined from separate stopped-flow reactions in which $\left[\operatorname{Ir}(\mathrm{IV}) \mathrm{Cl}_{6}\right]^{2-}$ was mixed with the appropriate buffer. Potentials obtained from multiple time points in the pseudo-equilibrium region were averaged to obtain a potential for each stopped-flow reaction. The results from three different stopped-flow experiments were then averaged to obtain the potentials reported here. $\operatorname{The}\left[\operatorname{Ir}(\mathrm{IV}) \mathrm{Cl}_{6}\right]^{2-} /\left[\mathrm{Ir}(\mathrm{III}) \mathrm{Cl}_{6}\right]^{3-}$ potential was measured to be $900 \mathrm{mV}$ vs. NHE, identical to the previously reported value. ${ }^{36}$

The values of $\mathrm{E}^{0}$ Comp-II determined in the $\mathrm{pH}$ range 8.0 to 9.5 are listed in Table 1. Plotting the values against $\mathrm{pH}$ reveals a linear relationship with a slope of $58 \mathrm{mV}$ (Figure 4). This value, which is very close to the expected value of $59 \mathrm{mV} / \mathrm{pH}$, suggests that the concentrations obtained in the pseudo-equilibrium region are indeed representative of equilibrium concentrations.

As noted above, due to its relatively low extinction coefficient, the concentration of $\left[\mathrm{Ir}(\mathrm{III}) \mathrm{Cl}_{6}\right]^{3-}$ at equilibrium cannot be determined directly from UV/visible spectroscopic measurements. As a result, previous investigations of the reduction potentials of HRP compounds I and II made the assumption that one equivalent of $\left[\operatorname{Ir}(\mathrm{III}) \mathrm{Cl}_{6}\right]^{3-}$ was generated for every equivalent of compound I and/or compound II obtained. ${ }^{30,37}$ George, however, noted in his studies with metmyoglobin that $\sim 1.5$ equivalents of $\left[\mathrm{Ir}(\mathrm{IV}) \mathrm{Cl}_{6}\right]^{2-}$ were consumed for each equivalent of ferryl myoglobin generated. The consumption of extra oxidizing equivalents was attributed to "reduction of the potassium chloriridate by other reducing groups, either on the protein or present as impurities in the preparation". ${ }^{38}$

In line with George's observation, we have found that the ratio of $\left[\left[\operatorname{Ir}(\mathrm{III}) \mathrm{Cl}_{6}\right]^{3-}\right] /[\mathrm{CYP} 158$ $\mathrm{II}]$ in the pseudo-equilibrium region is $\sim 2.2$, indicating that $\sim$ twice as much $\left[\operatorname{Ir}(\mathrm{IV}) \mathrm{Cl}_{6}\right]^{2-}$ had been consumed as CYP158-II generated. It is known that CYP158 possess several tyrosines in close proximity to the active site. ${ }^{33,34}$ We have shown that two of these (Tyr-352, Tyr-318) are oxidized during the reaction of meta-chloroperbenzoic acid with ferric CYP158. ${ }^{5}$ The most readily oxidized is Tyr-352, a solvent-exposed residue, which is adjacent to the Cys-353 thiolate ligand. ${ }^{5}$ Substituting a Phe at position 352 drops the $\left[\left[\operatorname{Ir}(\mathrm{III}) \mathrm{Cl}_{6}\right]^{3-}\right] /[\mathrm{CYP} 158-\mathrm{II}]$ ratio to $\sim 1.4$, while the double mutation (Y352F, Y318F) drops ratio to $\sim 1$. The reduction potentials and $\left[\left[\operatorname{Ir}(\mathrm{III}) \mathrm{Cl}_{6}\right]^{3-}\right] /[\mathrm{CYP} 158-\mathrm{II}]$ ratios for the wild type 
and mutant enzymes at $\mathrm{pH} 8.3$ are listed in Table 2. These potentials of the WT and mutant enzymes span a range of $30 \mathrm{mV}$, which is equivalent to $<1 \mathrm{kcal} / \mathrm{mol}$ in bond strength.

In concluding this section, we note that we have considered the loss of $\left[\operatorname{Ir}(\mathrm{IV}) \mathrm{Cl}_{6}\right]^{2-}$ oxidizing equivalents (either due to hydrolysis and/or to protein side-chain oxidation) in effort to obtain the most accurate potentials possible. However, we have found that, in practice, these losses can be ignored without any significant impact on the measured potentials or bond strengths. Excluding losses due to hydrolysis and side chain oxidation from our analyses (which is equivalent to assuming that $\left[\left[\operatorname{Ir}(\mathrm{III}) \mathrm{Cl}_{6}\right]^{3-}\right] /[\mathrm{CYP} 158-\mathrm{II}]=1$ for the wild type enzyme) changes the potentials obtained by an average of $20 \mathrm{mV}$.

\section{Experimental and Theoretical Bond Strengths}

A goal of our investigations is to map out the ground state thermodynamics of $\mathrm{C}-\mathrm{H}$ bond activation in cytochrome $\mathrm{P} 450$. The redox titrations outlined above have provided potentials, which can be used to determine the $\mathrm{D}(\mathrm{O}-\mathrm{H})_{\text {Ferric }}$ of the ferric water bound enzyme. Using the values listed in Table 1 and Table 2, one obtains $90 \pm 1 \mathrm{kcal} / \mathrm{mol}$ for this bond.

$\left[\operatorname{Ir}(\mathrm{IV}) \mathrm{Cl}_{6}\right]^{2-}$ cannot be used to access the $\mathrm{E}^{0}{ }^{\prime}$ Comp-I couple, as $\left[\operatorname{Ir}(\mathrm{IV}) \mathrm{Cl}_{6}\right]^{2-}$ does not have enough driving force to oxidize P450-II to P450-I. To provide insight into the strength of the $\mathrm{O}-\mathrm{H}$ bond in compound II, we sought to examine the ability of density functional calculations to predict $\mathrm{O}-\mathrm{H}$ bond strengths for iron-porphyrin complexes. It has been shown that a semi-empirical application of the restricted open-shell (ROS) DFT method can yield $\mathrm{O}-\mathrm{H}$ bond strengths with an average deviation of $\sim 1 \mathrm{kcal} / \mathrm{mol}$ from experimentally determined values. ${ }^{32}$ However, while the semi-empirical ROS method has been successfully applied to a large number of molecular systems, its utility for transition metal complexes has not been tested.

Using the ROS method (see methods section) as described by Wright and coworkers ${ }^{32}$, we calculated $\mathrm{O}-\mathrm{H}$ bond strengths associated with charge neutral $\mathrm{H}$-atom reductions for three experimentally determined iron-porphyrin redox couples: the $\mathrm{Fe}(\mathrm{IV}) \mathrm{OH} / \mathrm{Fe}(\mathrm{III}) \mathrm{OH}_{2}$ couple of $\mathrm{P} 450$ reported here, the $\mathrm{Fe}(\mathrm{IV}) \mathrm{O} / \mathrm{Fe}(\mathrm{III}) \mathrm{OH}$ couple of HRP reported by Hayashi and Yamazaki, ${ }^{30}$ and the $\mathrm{Fe}(\mathrm{IV}) \mathrm{O}\left(\mathrm{Por}^{\circ}\right) / \mathrm{Fe}(\mathrm{III}) \mathrm{OH}_{2}$ (Por) couple for the thiolate-ligated compound I intermediate of aromatic peroxidase (APO, vida infra) reported by Groves and coworkers. ${ }^{31}$

The ROS calculations were performed on simple iron-porphine models possessing the appropriate proximal ligand (methyl thiolate or imidazole). Calculated BDFEs (and their associated redox potentials) were found to be within $1 \mathrm{kcal} / \mathrm{mol}$ of the values determined by experiment. ${ }^{39}$ Bond strengths obtained from theory (experiment) for the ferric hydroxide form of HRP are $85(85) \mathrm{kcal} / \mathrm{mol},{ }^{30}$ while the values obtained for the ferric water bound form of $\mathrm{P} 450$ are $\mathrm{D}(\mathrm{O}-\mathrm{H})_{\text {Ferric }}=89(90) \mathrm{kcal} / \mathrm{mol}$. Additionally, the two-electron potential for reduction of a thiolate ligated compound $\mathrm{I}$ was calculated to be $\mathrm{E}^{0}{ }^{\prime} \mathrm{Comp-I} / \mathrm{Ferric}=1.09 \mathrm{~V}$ $(\mathrm{pH} 7)$, which compares well to the value of $1.12 \mathrm{~V}(\mathrm{pH} 7)$ obtained from experiments on APO-I. ${ }^{31}$ 
The ROS method has provided results in good agreement with three different experimentally determined redox couples. Importantly, two of these couples involve the thiolate-ligated compound I and compound II species that define $D(O-H)_{C o m p-I I}$. This suggests that the method can provide an accurate value for the $\mathrm{O}-\mathrm{H}$ bond strength for $\mathrm{P} 450-\mathrm{II}$ as well as the associated P450-I reduction potential. Application of the ROS method to the P450-I/P450-II couple provides a $\mathrm{D}(\mathrm{O}-\mathrm{H})_{\text {Comp-II }}$ bond strength of $95 \mathrm{kcal} / \mathrm{mol}$ and a proton coupled reduction potential of $\mathrm{E}^{0}$ ' Comp-I $=1.22 \mathrm{~V}$ at $\mathrm{pH} 7.0$.

\section{DISCUSSION AND CONCLUSION}

P450s are best known for their role in hydrocarbon oxygenations, but the enzymes can also perform desaturation and carbon-carbon bond cleaving reactions. P450s have been shown to play a role in the generation of vinyl carbamate from ethyl carbamate (a known carcinogenic pathway), the desaturation of testosterone to give $17 \beta$-hydroxy-4,6-androstadiene-3-one, the dehydrogenation of acetaminophen to iminoquinone (which is responsible for hepatic necrosis in high doses), and the production of $\mathrm{C}_{\mathrm{n}-1}$ alkenes from $\mathrm{C}_{\mathrm{n}}$ fatty acids..$^{23,27-29,40}$ All of these transformations involve an initial $\mathrm{H}$-atom abstraction by compound I to form an iron(IV)hydroxide species (i.e. compound II) and a substrate radical. However, instead of collapsing to give the hydroxylated product, P450-II oxidizes the substrate a second time. This oxidation can involve either direct $\mathrm{H}$-atom abstraction or a proton-coupled oxidation of the substrate radical. The P450-II reduction potential and $\mathrm{D}(\mathrm{O}-\mathrm{H})_{\text {Ferric }}$ reported here $(0.909$ $\mathrm{mV}$ at $\mathrm{pH} 8.3$, and $90 \mathrm{kcal} / \mathrm{mol}$, respectively) provide the driving force in either case.

Reports of aqueous potentials associated with the charge neutral (i.e. H-atom) reduction of iron(IV)oxo and iron(IV)hydroxide heme-systems are rare. The enzyme horseradish peroxidase is the only system for which we have found direct measurements in the literature that can be associated with an O-H bond strength. ${ }^{30}$ Hayashi and Yamazaki, using techniques similar to those employed here (i.e. spectrophotometric titrations with ferricyanide), measured the iron(IV)oxo/iron(III)hydroxide couple in HRP. They obtained a value of $0.523 \mathrm{~V}$ at $\mathrm{pH} 11.2$, corresponding to an $\mathrm{O}-\mathrm{H}$ bond strength of $85 \mathrm{kcal} / \mathrm{mol}$ for the ferric hydroxide form of the enzyme. ${ }^{13}$

The direct measurement of $\mathrm{O}-\mathrm{H}$ bond strengths in a thiolate-ligated heme system has not been previously reported, but Groves and coworkers have used reaction kinetics to estimate the O-H bond strengths of the iron(IV)hydroxide and ferric water-bound forms of APO. ${ }^{41}$ APO is a thiolate-ligated heme enzyme that can utilize hydrogen peroxide to efficiently oxidize a number of unactivated hydrocarbons. Based on the rates of the oxidation of $p$ toluic acid and $p$-ethylbenzoic acid by APO compound I, a BDE of $\sim 103 \mathrm{kcal} / \mathrm{mol}$ (BDFE of $\sim 105 \mathrm{kcal} / \mathrm{mol}$ ) was estimated for the O-H bond of APO-II (a value that is $10 \mathrm{kcal} / \mathrm{mol}$ greater than the value predicted here for P450-II). ${ }^{39,41}$ Additional kinetic measurements, to determine the equilibrium constants for the reaction of APO with hypohalous acids, provided the two-electron potential for APO-I reduction, $\mathrm{E}^{0^{\prime}}$ Comp-I/Ferric $=1.12 \mathrm{~V}$ at $\mathrm{pH} 7 .^{31}$ From the one- and two-electron potentials of APO-I, one can obtain an APO-II reduction potential of $0.60 \mathrm{~V}(\mathrm{pH} 7)$, corresponding to an $\mathrm{O}-\mathrm{H}$ bond strength of $81 \mathrm{kcal} / \mathrm{mol}$ for the ferric water-bound form of the enzyme (which is $9 \mathrm{kcal} / \mathrm{mol}$ less than the value obtained for ferric P450.) 
Among heme proteins, only those with axial thiolate ligation are known to activate $\mathrm{C}-\mathrm{H}$ bonds. Evidence suggests that the thiolate ligand may play a dual role in this process, protecting the enzyme from oxidative damage, while increasing the reactivity of the ferryl oxygen towards hydrocarbons. ${ }^{5,42,43}$ How the thiolate increases the reactivity of compound I remains a topic of active research, and there are differing viewpoints regarding the factors that control/promote $\mathrm{C}-\mathrm{H}$ bond activation by metal-oxo complexes. ${ }^{2,3}$ Debate in the field centers upon on whether ground state thermodynamics play the dominant role in determining reactivity or whether some other property (e.g. oxyl-radical character, metaloxo basicity, metal-oxo spin state, the width of the activation barrier, or multi-state reactivity) can provide an intrinsic lowering of the activation barrier. ${ }^{10-19}$

Given that P450 and APO have similar coordination environments and reactivity (i.e. both possess thiolate-ligated hemes that efficiently oxygenate unactivated hydrocarbons), the bond strengths outlined above for these systems are surprising. One might expect these enzymes to possess similar thermodynamics for $\mathrm{C}-\mathrm{H}$ bond activation. It must be remembered, however, that the only potentials known from direct measurements on these systems are the two-electron potential of APO-I and the one-electron potential of P450-II. Using the values reported for these potentials $\left(\mathrm{E}^{0^{\prime}}\right.$ Comp-I/Ferric $=1.12 \mathrm{~V}, \mathrm{E}^{0^{\prime}}$ Comp-II $\left.=0.99 \mathrm{~V}\right)$, one can estimate a P450-II (or APO-II) O-H bond strength of $96 \mathrm{kcal} / \mathrm{mol}$, a value that is within $1 \mathrm{kcal} / \mathrm{mol}$ of the value $(95 \mathrm{kcal} / \mathrm{mol})$ predicted by ROS calculations on a simple thiolate-ligated iron-porphine model system. These same computational methods yield a two-electron reduction potential of $\mathrm{E}^{0}$ Comp-I/Ferric $=1.09 \mathrm{~V}$ for a thiolate-ligated compound I at $\mathrm{pH} 7$, a value that differs by only $0.03 \mathrm{~V}(<1 \mathrm{kcal} / \mathrm{mol})$ from the experimentally determined two-electron potential for APO-I reduction. ${ }^{31}$

The $95 \mathrm{kcal} / \mathrm{mol} \mathrm{BDFE}$ predicted for $\mathrm{D}(\mathrm{O}-\mathrm{H})_{\text {Comp-II }}$ in these thiolate ligated systems is interesting given the highly reactive nature of thiolate ligated compound I species. In the synthetic literature, it is common practice to estimate (or bracket) metal-hydroxide bond strengths based on the strength of the $\mathrm{C}-\mathrm{H}$ bonds that the parent oxo-complex can oxidize, and second order rate constants for the reaction of synthetic metal oxo complexes with organic substrates have been found to be severely attenuated when $\mathrm{BDE}_{\mathrm{C}-\mathrm{H}} \geq \mathrm{BDE}_{\mathrm{O}-\mathrm{H}}$. 16,44-47 However, direct comparisons of solution second order rate constants for molecular and enzymatic systems are problematic. Reactions depend critically upon collisions between reactive species, and enzymatic systems bind their substrates in close proximity to the metaloxo moiety, increasing residence time near the transition state.

Experiments with CYP119 have shown that P450-I oxidizes the $\omega-1$ position of C6-C12 fatty acids (BDFE $101 \mathrm{kcal} / \mathrm{mol}$ ) at $10^{4}-10^{7} \mathrm{M}^{-1} \mathrm{~s}^{-1}$, while the oxidation of bound substrate can exceed $1400 \mathrm{~s}^{-1}$ at $4^{\circ} \mathrm{C}^{4}$ The rapid rate of bound substrate oxidation would appear to be at odds with theoretical investigations that have typically predicted activation barriers on the order of $18-20 \mathrm{kcal} / \mathrm{mol}$ for $\mathrm{H}$-atom abstraction by P450-I. ${ }^{48-51}$ However it has been argued that zero point effects, dispersion interactions, and proton tunneling can reduce calculated barriers to values that are consistent with experimentally determined rate constants. ${ }^{48-53}$

Recently there has been renewed interest in the role that quantum mechanical tunneling plays in metal-oxo mediated C-H bond activation. ${ }^{14,15,54-56}$ It has been suggested that the 
ligand trans to the oxo ligand plays an important role in shaping the potential energy surface to promote $\mathrm{H}$-atom transfer. In theoretical investigations of the oxidation of 9,10dihydroanthracene (DHA) and cyclohexadiene (CHD) by series of tetramethylcyclam (TMC) supported iron(IV)oxo complexes, it was found that donating axial ligands lead to a reduction in barrier width, increasing proton tunneling efficiency. ${ }^{15}$ For the oxidation of CHD by series of (TMC)Fe ${ }^{\mathrm{IV}} \mathrm{O}$ complexes with different axial ligands, a thiolate ligated species was found to have the narrowest barrier for $\mathrm{H}$-atom transfer. ${ }^{56}$ Based on their work, Klein and coworkers argued that the thiolate ligand has a privileged role in these oxidations, increasing the reactivity by shaping the potential energy surface and inducing significant tunneling. ${ }^{15}$

Mayer has convincingly argued that thermodynamics (and not oxyl-radical character, oxo basicity, spin state, or quantum mechanical tunneling) must be the key factor that determines the reactivity for single step $\mathrm{H}$-atom transfers. ${ }^{13}$ This is because the ratio of the forward and reverse rate constants is dictated by the equilibrium constant. For an endergonic reaction, a large rate constant in the forward direction means an even larger rate constant in the reverse direction.

Consider for example the oxidation of dodecanoic acid at the $\omega$ - 1 position by CYP119-I. ${ }^{4}$ The results presented here indicate that the $\mathrm{H}$-atom abstraction step is $\sim 6 \mathrm{kcal} / \mathrm{mol}$ uphill. Given these thermodynamics, if P450-I abstracts an $\mathrm{H}$-atom from the substrate with a rate constant of $2000 \mathrm{~s}^{-1}$, the rate constant for the return of the $\mathrm{H}$-atom to the substrate radical must be $\sim 10^{8} \mathrm{~s}^{-1}$. Thus, it can be inferred that $\mathrm{P} 450$ function hinges upon a rapid rebound step, in which the newly formed hydroxide ligand and the substrate radical combine to yield hydroxylated product.

Using radical clocks, the rebound step in $\mathrm{P} 450$ s has been estimated to have a rate constant on the order of $10^{10}$ to $10^{11} \mathrm{~s}^{-1} .^{57} \mathrm{~A}$ rate constant of this magnitude precludes back transfer of the $\mathrm{H}$-atom to substrate, based on the rate constants and thermodynamics outlined above. Importantly, a rapid rebound step provides a mechanism by which an increase in the forward rate constant for $\mathrm{H}$-atom abstraction creates a more reactive hydroxylating intermediate irrespective of the equilibrium constant for $\mathrm{H}$-atom transfer (Figure 5). The activation barrier may still be a function of ground state thermodynamics, but, given the rapid rate of rebound, it is conceivable that some other property of the system (oxyl-radical character, metal-oxo basicity, quantum mechanical tunneling, protein dynamics, etc.) could provide an intrinsic lowering of the barrier, increasing the rate constant for $\mathrm{H}$-atom abstraction without the penalty of an increased back transfer rate.

Recently we reported an isoelectronic and isostructural perturbation to P450-I that may provide insight into the ability of these factors to augment the contributions of thermodynamics to reactivity. ${ }^{3}$ Through the use of a cysteine auxotrophic cell line, we obtained a selenocysteine-ligated variant of CYP119. Although ROS calculations indicate that $\mathrm{D}(\mathrm{O}-\mathrm{H})_{\mathrm{Comp}-\mathrm{II}}$ is identical for the thiolate- and selenolate-ligated systems, experiments have revealed that SeCYP119-I is significantly more reactive towards C-H bonds. This elevated reactivity has been attributed to increased electron donation from the selenolate 
ligand. Just how this increased electron donation manifests itself in terms of a more reactive P450-I remains to be determined.

\section{Experimental and Computational Methods}

Materials:

Potassium hexachloroiridate(IV) was obtained from Sigma Aldrich. CYP158 was overexpressed in BL21 cells and purified as reported previously. ${ }^{5}$ Only protein fractions with an $\mathrm{Rz} \geq 2$ were used for experiments.

\section{Stopped-Flow Spectrophotometry:}

Spectral changes were monitored using an SFM-400 stopped flow rapid scan spectrometer (Bio-Logic SA, Claix, France). An L7893 light source (Hamamatasu, Tokyo, Japan) and a TIDAS photodiode was used to collect absorption data. All experiments were performed at $7^{\circ} \mathrm{C}$.

\section{Cyp158A2 Reaction:}

$20 \mathrm{uM}$ CYP158A2 in 25mM tris-HCl buffer ( $\mathrm{pH} \mathrm{8,} \mathrm{8.3,} \mathrm{8.7,} \mathrm{9.0,} \mathrm{9.3,} \mathrm{and} \mathrm{9.5)} \mathrm{was} \mathrm{mixed}$ with $100 \mathrm{uM}$ (or $200 \mathrm{uM}$ ) $\mathrm{K}_{2} \mathrm{IrCl}_{6}$, to yield final concentrations of $10 \mathrm{uM}$ and $50 \mathrm{uM}$ (or 100 $\mathrm{uM}$ ), respectively. A fresh stock solution of $2.5 \mathrm{mM} \mathrm{K}_{2} \mathrm{IrCl}_{6}$ in nanopure water was made before each set of experiments and diluted as necessary. The $\mathrm{pH}$ of the final reaction mixture was measured and found to be the same as the $\mathrm{pH}$ of the protein solution before mixing.

\section{Extinction Coefficients Used to Determine Concentrations:}

The following extinction coefficients were used: ferric CYP158 $\left(\varepsilon_{4} 16 \mathrm{~nm}=100,000 \mathrm{M}^{-1} \mathrm{~cm}\right.$ $\left.{ }^{-1}\right)$, CYP158-II $\left(\varepsilon_{426 \mathrm{~nm}}=69,000 \mathrm{M}^{-1} \mathrm{~cm}^{-1}\right),\left[\operatorname{Ir}(\mathrm{IV}) \mathrm{Cl}_{6}\right]^{2-}\left(\varepsilon_{491 \mathrm{~nm}}=3,064 \mathrm{M}^{-1} \mathrm{~cm}^{-1}\right)$, $\left[\mathrm{Ir}(\mathrm{III}) \mathrm{Cl}_{6}\right]^{3-}\left(\varepsilon_{491 \mathrm{~nm}} \sim 100 \mathrm{M}^{-1} \mathrm{~cm}^{-1}\right)$. Further details on these values, how they were used, and how the concentration of $\left[\mathrm{Ir}(\mathrm{III}) \mathrm{Cl}_{6}\right]^{3-}$ was determined can be found in Supporting Information.

\section{Calculations:}

$\mathrm{O}-\mathrm{H}$ bond strengths were calculated using the ROS method as described by Wright and coworkers. ${ }^{32}$ Calculations were performed at the MLM2, which involves geometry optimizations and frequency analyses at the UB3LYP/6-31G(d) level, followed by a single point calculation at the ROB3LYP/6-311+G(2d,2p) level. Zero point energies and enthalpy corrections were scaled by 0.9806 and 0.9989 , respectively. A key feature of the technique as described by Wright and coworkers is that the energy of atomic hydrogen is set equal to its exact value $-1.0 \mathrm{Ry}$. Calculations were performed on simple iron-porphine models with the appropriate axial ligands. All calculations were performed with Gaussian 09. ${ }^{58}$

\section{Relationship between Redox Potential and Bond Strength:}

For an aqueous proton-coupled reduction, the relationship between the potential (vs. NHE) and the bond strength (in $\mathrm{kcal} / \mathrm{mol}$ ) is given by: 


$$
\mathrm{D}(\mathrm{O}-\mathrm{H})=23.06 * \mathrm{E}^{0^{\prime}}+1.37 * \mathrm{pH}+57.6
$$

For the two-electron two-proton coupled reduction of compound I to ferric enzyme, the relationship is given by:

$$
\mathrm{D}(\mathrm{O}-\mathrm{H})_{\mathrm{comp}-\mathrm{II}}+\mathrm{D}(\mathrm{O}-\mathrm{H})_{\mathrm{Ferric}}=2\left(23.06 * \mathrm{E}^{0^{\prime}}+1.37 * \mathrm{pH}+57.6\right) \quad \text { Eq. } 2
$$

\section{Supplementary Material}

Refer to Web version on PubMed Central for supplementary material.

\section{ACKNOWLEDGMENT}

The authors thank Julio C. Calixto for insights gained during his efforts to measure the P450-II reduction potential.

Funding Sources

This work was supported by the NIH (R01-GM101390).

\section{ABBREVIATIONS}

$\begin{array}{ll}\text { P450 } & \text { cytochrome P450 } \\ \text { HRP } & \text { horseradish peroxidase }\end{array}$

\section{REFERENCES}

1. Hartwig JF; Larsen MA Undirected, Homogeneous C-H Bond Functionalization: Challenges and Opportunities. ACS Cent. Sci 2016, 2, 281. [PubMed: 27294201]

2. Krest CM; Silakov A; Rittle J; Yosca TH; Onderko EL; Calixto JC; Green MT Significantly shorter $\mathrm{Fe}-\mathrm{S}$ bond in cytochrome $\mathrm{P} 450-\mathrm{I}$ is consistent with greater reactivity relative to chloroperoxidase. Nat. Chem 2015, 7, 696. [PubMed: 26291940]

3. Onderko EL; Silakov A; Yosca TH; Green MT Characterization of a selenocysteine-ligated P450 compound I reveals direct link between electron donation and reactivity. Nat. Chem 2017, 9, 623. [PubMed: 28644466]

4. Rittle J; Green MT Cytochrome P450 Compound I: Capture, Characterization, and C-H Bond Activation Kinetics. Science 2010, 330, 933. [PubMed: 21071661]

5. Yosca TH; Rittle J; Krest CM; Onderko EL; Silakov A; Calixto JC; Behan RK; Green MT Iron(IV)hydroxide $\mathrm{pKa}$ and the role of thiolate ligation in $\mathrm{C}-\mathrm{H}$ bond activation by cytochrome $\mathrm{P} 450$; and the Role of Thiolate Ligation in C-H Bond Activation by Cytochrome P450. Science 2013, 342, 825. [PubMed: 24233717]

6. Oritz de Montellano PR Cytochrome p450: Structure, Mechanism, and Biochemistry, Third Edition. Kluwer academic/plenum publishers, New York 2005.

7. Ortiz de Montellano PR Hydrocarbon Hydroxylation by Cytochrome P450 Enzymes. Chem. Rev 2010, 110, 932. [PubMed: 19769330]

8. Denisov IG; Makris TM; Sligar SG; Schlichting I Structure and Chemistry of Cytochrome P450. Chem. Rev 2005, 105, 2253. [PubMed: 15941214]

9. Krest CM; Onderko EL; Yosca TH; Calixto JC; Karp RF; Livada J; Rittle J; Green MT Reactive Intermediates in Cytochrome P450 Catalysis. J. Biol. Chem 2013, 288, 17074. [PubMed: 23632017] 
10. Mayer JM Understanding Hydrogen Atom Transfer: From Bond Strengths to Marcus Theory. Acc. Chem. Res 2011, 44, 36. [PubMed: 20977224]

11. Dietl N; Schlangen M; Schwarz H Thermal Hydrogen-Atom Transfer from Methane: The Role of Radicals and Spin States in Oxo-Cluster Chemistry. Angew. Chem 2012, 51, 5544. [PubMed: 22431300]

12. Lai W; Li C; Chen H; Shaik S Hydrogen-Abstraction Reactivity Patterns from A to Y: The Valence Bond Way. Angew. Chem 2012, 51, 5556. [PubMed: 22566272]

13. Saouma CT; Mayer JM Do spin state and spin density affect hydrogen atom transfer reactivity? Chem. Sci 2014, 5, 21.

14. Mandal D; Shaik S Interplay of Tunneling, Two-State Reactivity, and Bell-Evans-Polanyi Effects in C-H Activation by Nonheme Fe(IV)O Oxidants. J. Am. Chem. Soc 2016, 138, 2094. [PubMed: 26824716]

15. Klein J; Mandal D; Ching WM; Mallick D; Que L Jr.; Shaik S Privileged Role of Thiolate as the Axial Ligand in Hydrogen Atom Transfer Reactions by Oxoiron(IV) Complexes in Shaping the Potential Energy Surface and Inducing Significant H-Atom Tunneling. J. Am. Chem. Soc 2017, 139, 18705. [PubMed: 29179544]

16. Baglia RA; Prokop-Prigge KA; Neu HM; Siegler MA; Goldberg DP Mn(V)(O) versus Cr(V)(O) Porphyrinoid Complexes: Structural Characterization and Implications for Basicity Controlling HAtom Abstraction. J. Am. Chem. Soc 2015, 137, 10874. [PubMed: 26295412]

17. Kang Y; Chen H; Jeong YJ; Lai W; Bae EH; Shaik S; Nam W Enhanced reactivities of iron(IV)oxo porphyrin pication radicals in oxygenation reactions by electron-donating axial ligands. Chemistry 2009, 15, 10039. [PubMed: 19697378]

18. Usharani D; Lacy DC; Borovik AS; Shaik S Dichotomous hydrogen atom transfer vs protoncoupled electron transfer during activation of $\mathrm{X}-\mathrm{H}$ bonds $(\mathrm{X}=\mathrm{C}, \mathrm{N}, \mathrm{O})$ by nonheme iron-oxo complexes of variable basicity. J. Am. Chem. Soc 2013, 135, 17090. [PubMed: 24124906]

19. Parsell TH; Yang MY; Borovik AS C-H Bond Cleavage with Reductants: Re-Investigating the Reactivity of Monomeric Mn-III/IV-Oxo Complexes and the Role of Oxo Ligand Basicity. J. Am. Chem. Soc 2009, 131, 2762. [PubMed: 19196005]

20. Gardner KA; Kuehnert LL; Mayer JM Hydrogen Atom Abstraction by Permanganate: Oxidations of Arylalkanes in Organic Solvents. Inorg. Chem 1997, 36, 2069. [PubMed: 11669825]

21. Mayer JM Hydrogen Atom Abstraction by Metal-Oxo Complexes: Understanding the Analogy with Organic Radical Reactions. Acc. Chem. Res 1998, 31, 441.

22. Warren JJ; Tronic TA; Mayer JM Thermochemistry of Proton-Coupled Electron Transfer Reagents and its Implications. Chem. Rev 2010, 110, 6961. [PubMed: 20925411]

23. Guengerich FP; Kim DH Enzymic oxidation of ethyl carbamate to vinyl carbamate and its role as an intermediate in the formation of 1,N6-ethenoadenosine. Chem. Res. Toxicol 1991, 4, 413. [PubMed: 1912327]

24. Oritz de Montellano PR Cytochrome-P-450 Catalysis - Radical Intermediates and Dehydrogenation Reactions. Trends. Pharmacol. Sci 1989, 10, 354. [PubMed: 2690426]

25. Guan XM; Fisher MB; Lang DH; Zheng YM; Koop DR; Rettie AE Cytochrome P450-dependent desaturation of lauric acid: isoform selectivity and mechanism of formation of 11-dodecanoic acid. Chem. Biol. Interact 1998, 110, 103. [PubMed: 9566728]

26. Newcomb M; Chandrasena REP; Lansakara-P DSP; Kim HY; Lippard SJ; Beauvais LG; Murray LJ; Izzo V; Hollenberg PF; Coon MJ Desaturase reactions complicate the use of norcarane as a mechanistic probe. Unraveling the mixture of twenty-plus products formed in enzyme-catalyzed oxidations of norcarane. J. Org. Chem 2007, 72, 1121. [PubMed: 17288366]

27. Ortiz de Montellano PR; Nelson SD Rearrangement Reactions Catalyzed by Cytochrome P450s. Arch. Biochem. Biophys 2011, 507, 95. [PubMed: 20971058]

28. Grant JL; Mitchell ME; Makris TM Catalytic strategy for carbon-carbon bond scission by the cytochrome P450 OleT. Proc. Natl. Acad. Sci. U.S.A 2016, 113, 10049. [PubMed: 27555591]

29. Hsieh CH; Huang X; Amaya JA; Rutland CD; Keys CL; Groves JT; Austin RN; Makris TM The Enigmatic P450 Decarboxylase OleT Is Capable of, but Evolved To Frustrate, Oxygen Rebound Chemistry. Biochemistry 2017, 56, 3347. [PubMed: 28603981] 
30. Hayashi Y; Yamazaki I The oxidation-reduction potentials of compound I/compound II and compound II/ferric couples of horseradish peroxidases A2 and C. J. Biol. Chem 1979, 254, 9101. [PubMed: 39073]

31. Wang X; Peter S; Ullrich R; Hofrichter M; Groves JT Driving Force for Oxygen-Atom Transfer by Heme-Thiolate Enzymes. Angew. Chem 2013, 52, 9238. [PubMed: 23825007]

32. DiLabio GA; Pratt DA; LoFaro AD; Wright JS Theoretical Study of $\mathrm{X}-\mathrm{H}$ Bond Energetics $(\mathrm{X}=\mathrm{C}$, N, O, S): Application to Substituent Effects, Gas Phase Acidities, and Redox Potentials. J. Phys. Chem. A 1999, 103, 1653.

33. Zhao B; Guengerich FP; Voehler M; Waterman MR Role of active site water molecules and substrate hydroxyl groups in oxygen activation by cytochrome P450 158A2 - A new mechanism of proton transfer. J. Biol. Chem 2005, 280, 42188. [PubMed: 16239228]

34. Zhao B; Guengerich FP; Bellamine A; Lamb DC; Izumikawa M; Lei L; Podust LM; Sundaramoorthy M; Kalaitzis JA; Reddy LM; Kelly SL; Moore BS; Stec D; Voehler M; Falck JR; Shimada T; Waterman MR Binding of two flaviolin substrate molecules, oxidative coupling, and crystal structure of Streptomyces coelicolor A3(2) cytochrome P450 158A2. J. Biol. Chem 2005, 280, 11599. [PubMed: 15659395]

35. Zhao Y; Hernandez-Pagan EA; Vargas-Barbosa NM; Dysart JL; Mallouk TE A High Yield Synthesis of Ligand-Free Iridium Oxide Nanoparticles with High Electrocatalytic Activity. J. Phys. Chem. Lett 2011, 2, 402.

36. Farhangrazi ZS; Copeland BR; Nakayama T; Amachi T; Yamazaki I; Powers LS OxidationReduction Properties of Compounds I and II of Arthromyces ramosus Peroxidase. Biochemistry 1994, 33, 5647. [PubMed: 8180190]

37. He B; Sinclair R; Copeland BR; Makino R; Powers LS; Yamazaki I The structure-function relationship and reduction potentials of high oxidation states of myoglobin and peroxidase. Biochemistry 1996, 35, 2413. [PubMed: 8652584]

38. George P; Irvine DH The reaction of metmyoglobin with strong oxidizing agents. Biochem. J 1954, 58, 188. [PubMed: 13208570]

39. Assuming the oxidant and its H-atom reduced form (e.g. P450-I and P450-II, respectively) have the same entropy of solvation $\left(\mathrm{S}_{\mathrm{Solv}}{ }^{0}\right.$ ) the $\mathrm{O}-\mathrm{H}$ BDFE can be obtained by adding $1.8 \mathrm{kcal} / \mathrm{mol}$ to the calculated BDE. ${ }^{22}$.

40. Nagata K; Liberato DJ; Gillette JR; Sasame HA An unusual metabolite of testosterone. 17 betaHydroxy-4,6-androstadiene-3-one. Drug. Metab. Dispos 1986, 14, 559. [PubMed: 2876862]

41. Wang X; Peter S; Kinne M; Hofrichter M; Groves JT Detection and Kinetic Characterization of a Highly Reactive Heme-Thiolate Peroxygenase Compound I. J. Am. Chem. Soc 2012, 134, 12897. [PubMed: 22827262]

42. Yosca TH; Ledray AP; Ngo J; Green MT A new look at the role of thiolate ligation in cytochrome P450. J. Biol. Inorg. Chem 2017, 22, 209. [PubMed: 28091754]

43. Green MT; Dawson JH; Gray HB Oxoiron(IV) in Chloroperoxidase Compound II Is Basic: Implications for P450 Chemistry. Science 2004, 304, 1653. [PubMed: 15192224]

44. Gupta R; Borovik AS Monomeric Mn-III/II and Fe-III/II complexes with terminal hydroxo and oxo ligands: Probing reactivity via O-H bond dissociation energies. J. Am. Chem. Soc 2003, 125, 13234. [PubMed: 14570499]

45. Yin GC; Danby AM; Kitko D; Carter JD; Scheper WM; Busch DH Understanding the selectivity of a moderate oxidation catalyst: Hydrogen abstraction by a fully characterized, activated catalyst, the robust dihydroxo manganese(IV) complex of a bridged cyclam. J. Am. Chem. Soc 2007, 129, 1512. [PubMed: 17249671]

46. Yin GC; Danby AM; Kitko D; Carter JD; Scheper WM; Busch DH Oxidative Reactivity Difference among the Metal Oxo and Metal Hydroxo Moieties: pH Dependent Hydrogen Abstraction by a Manganese(IV) Complex Having Two Hydroxide Ligands. J. Am. Chem. Soc 2008, 130, 16245. [PubMed: 18998682]

47. Feng Y; Gunnoe TB; Grimes TV; Cundari TR Octahedral [TpRu(PMe3)(2)OR](n+) complexes (Tp $=$ hydridotris(pyrazolyl) borate; $\mathrm{R}=\mathrm{H}$ or $\mathrm{Ph} ; \mathrm{n}=0$ or 1 ): Reactions at $\mathrm{Ru}(\mathrm{II})$ and $\mathrm{Ru}(\mathrm{III})$ oxidation states with substrates that possess carbon-hydrogen bonds. Organometallics 2006, 25, 5456. 
48. Zurek J; Foloppe N; Harvey JN; Mulholland AJ Mechanisms of reaction in cytochrome P450: Hydroxylation of camphor in P450cam. Org. Biomol. Chem 2006, 4, 3931. [PubMed: 17047872]

49. Shaik S; Kumar D; de Visser SP; Altun A; Thiel W Theoretical perspective on the structure and mechanism of cytochrome P450 enzymes. Chem. Rev 2005, 105, 2279. [PubMed: 15941215]

50. Shaik S; Cohen S; Wang Y; Chen H; Kumar D; Thiel W P450 Enzymes: Their Structure, Reactivity, and Selectivity-Modeled by QM/MM Calculations. Chem. Rev 2010, 110, 949. [PubMed: 19813749]

51. Schoneboom JC; Cohen S; Lin H; Shaik S; Thiel W Quantum mechanical/molecular mechanical investigation of the mechanism of $\mathrm{C}-\mathrm{H}$ hydroxylation of camphor by cytochrome $\mathrm{P} 450(\mathrm{cam})$ : Theory supports a two-state rebound mechanism. J. Am. Chem. Soc 2004, 126, 4017. [PubMed: 15038756]

52. Lonsdale R; Harvey JN; Mulholland AJ Inclusion of Dispersion Effects Significantly Improves Accuracy of Calculated Reaction Barriers for Cytochrome P450 Catalyzed Reactions. J. Phys. Chem. Lett 2010, 1, 3232.

53. Lonsdale R; Harvey JN; Mulholland AJ Effects of Dispersion in Density Functional Based Quantum Mechanical/Molecular Mechanical Calculations on Cytochrome P450 Catalyzed Reactions. J. Chem. Theory. Comput 2012, 8, 4637. [PubMed: 26605619]

54. Mandal D; Mallick D; Shaik S Kinetic Isotope Effect Determination Probes the Spin of the Transition State, Its Stereochemistry, and Its Ligand Sphere in Hydrogen Abstraction Reactions of Oxoiron(IV) Complexes. Acc. Chem. Res 2018, 51, 107. [PubMed: 29297671]

55. Mandal D; Ramanan R; Usharani D; Janardanan D; Wang B; Shaik S How does tunneling contribute to counterintuitive $\mathrm{H}$-abstraction reactivity of nonheme $\mathrm{Fe}(\mathrm{IV}) \mathrm{O}$ oxidants with alkanes? J. Am. Chem. Soc 2015, 137, 722. [PubMed: 25513834]

56. Bim D; Maldonado-Dominguez M; Rulisek L; Srnec M Beyond the classical thermodynamic contributions to hydrogen atom abstraction reactivity. Proc. Natl. Acad. Sci. U.S.A 2018, 115, E10287. [PubMed: 30254163]

57. Jiang YY; He X; de Montellano PRO Radical intermediates in the catalytic oxidation of hydrocarbons by bacterial and human cytochrome P450 enzymes. Biochemistry 2006, 45, 533. [PubMed: 16401082]

58. Frisch MJ; Trucks GW; Schlegel HB; Scuseria GE; Robb MA; Cheeseman JR; Scalmani G; Barone V, M. B; Petersson GA; Nakatsuji H; Caricato M; Li X, H. HP; Izmaylov AF; Bloino J, Z. G; Sonnenberg JL; Hada M; Ehara M; Toyota K; Fukuda R; Hasegawa J; Ishida M; Nakajima T; Honda Y; Kitao O; Nakai H; Vreven T; Montgomery JA Jr.; P. JE; Ogliaro F; Bearpark M; Heyd JJ; Brothers E; Kudin KN; Staroverov VN; Kobayashi R, N. J, Raghavachari K, Rendell A, Burant JC, Iyengar SS, Tomasi J, Cossi M, Rega N, Millam JM, Klene M, Knox JE, Cross JB, Bakken V, Adamo C, Jaramillo J, Gomperts R, Stratmann RE, Yazyev O, Austin AJ, Cammi R, Pomelli C, Ochterski JW, Martin RL, Morokuma K, Zakrzewski VG, Voth GA, Salvador P, Dannenberg JJ, Dapprich S,; Daniels AD; Farkas Ö, F. JB, Ortiz JV, Cioslowski J, and Fox DJ; Gaussian 09, Revision C.01 Gaussian Inc., Wallingford, CT, 2009: Wallingford CT. 

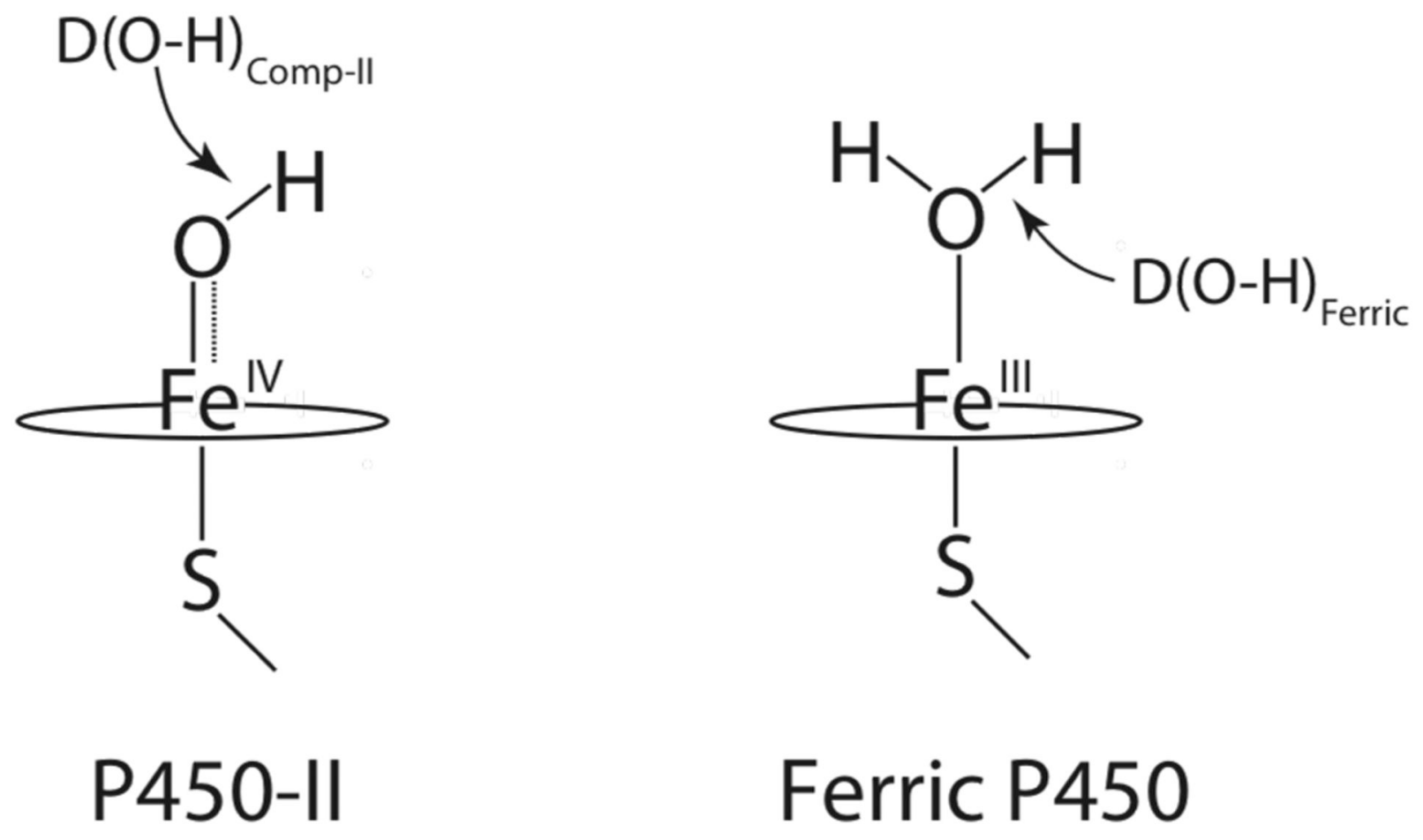

Figure 1.

Bonds strengths that define the ground state thermodynamics of $\mathrm{P} 450$ catalysis. $\mathrm{D}(\mathrm{O}-$ $\mathrm{H})_{\text {Comp-II }}$ is the strength of the $\mathrm{O}-\mathrm{H}$ bond in $\mathrm{P} 450$ compound $\mathrm{II}$. D $(\mathrm{O}-\mathrm{H})_{\text {Ferric }}$ is the $\mathrm{O}-\mathrm{H}$ bond strength in the ferric water-bound form of the enzyme. 


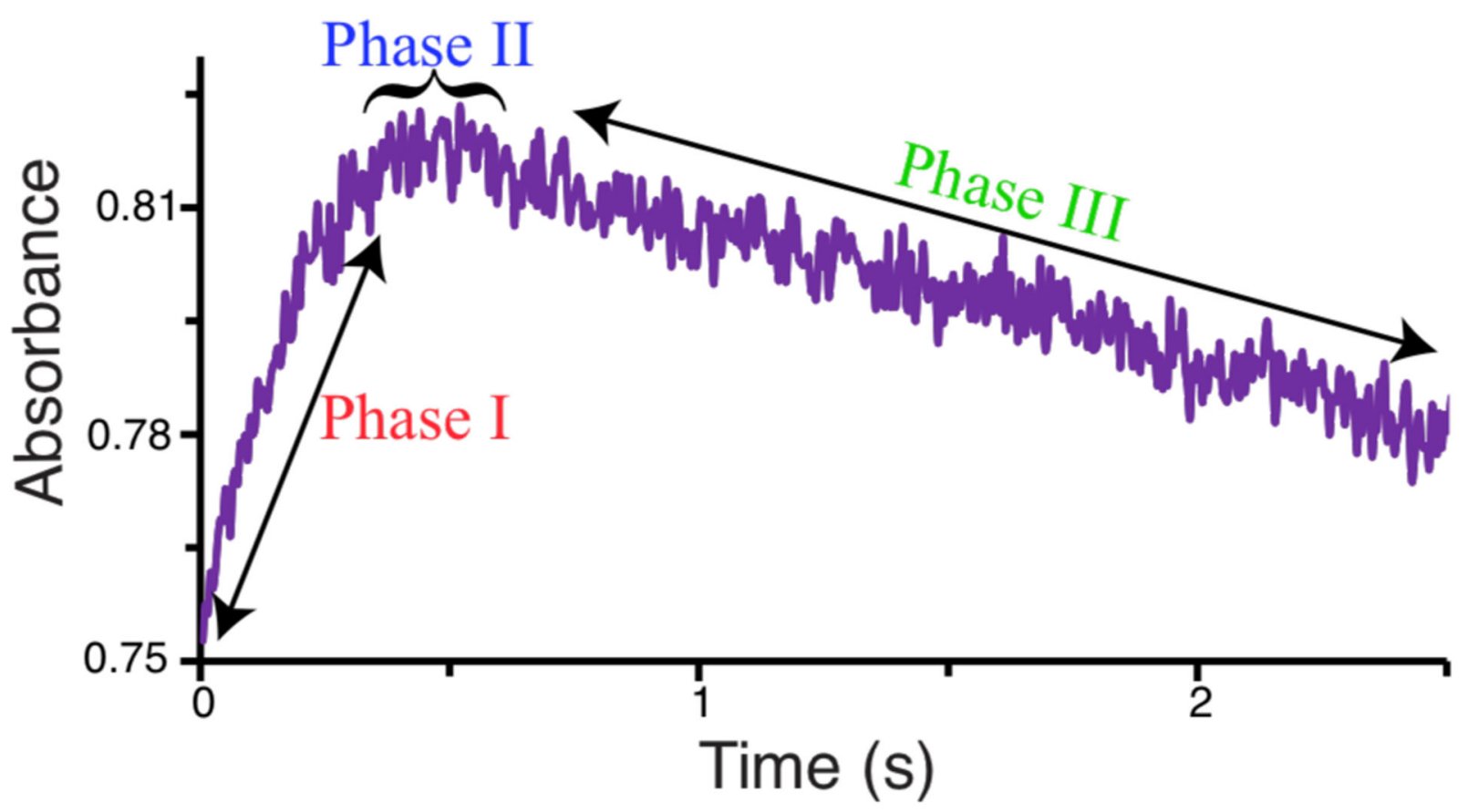

Figure 2.

Time trace at $430 \mathrm{~nm}$ of reaction between CYP158 and $\left[\mathrm{Ir}(\mathrm{IV}) \mathrm{Cl}_{6}\right]^{2-}$ at $\mathrm{pH}$ 8.3. The reaction can be divided into three distinct phases. It begins with Phase I, dominated by the forward reaction (i.e. formation of $\mathrm{P} 450-\mathrm{II}$ ). This is followed by a brief period of pseudoequilibrium, denoted by Phase II. This is the phase where the potentials are determined from the concentration of each species. This is followed by Phase III, which is dominated by decay of P450-II back to ferric enzyme. 


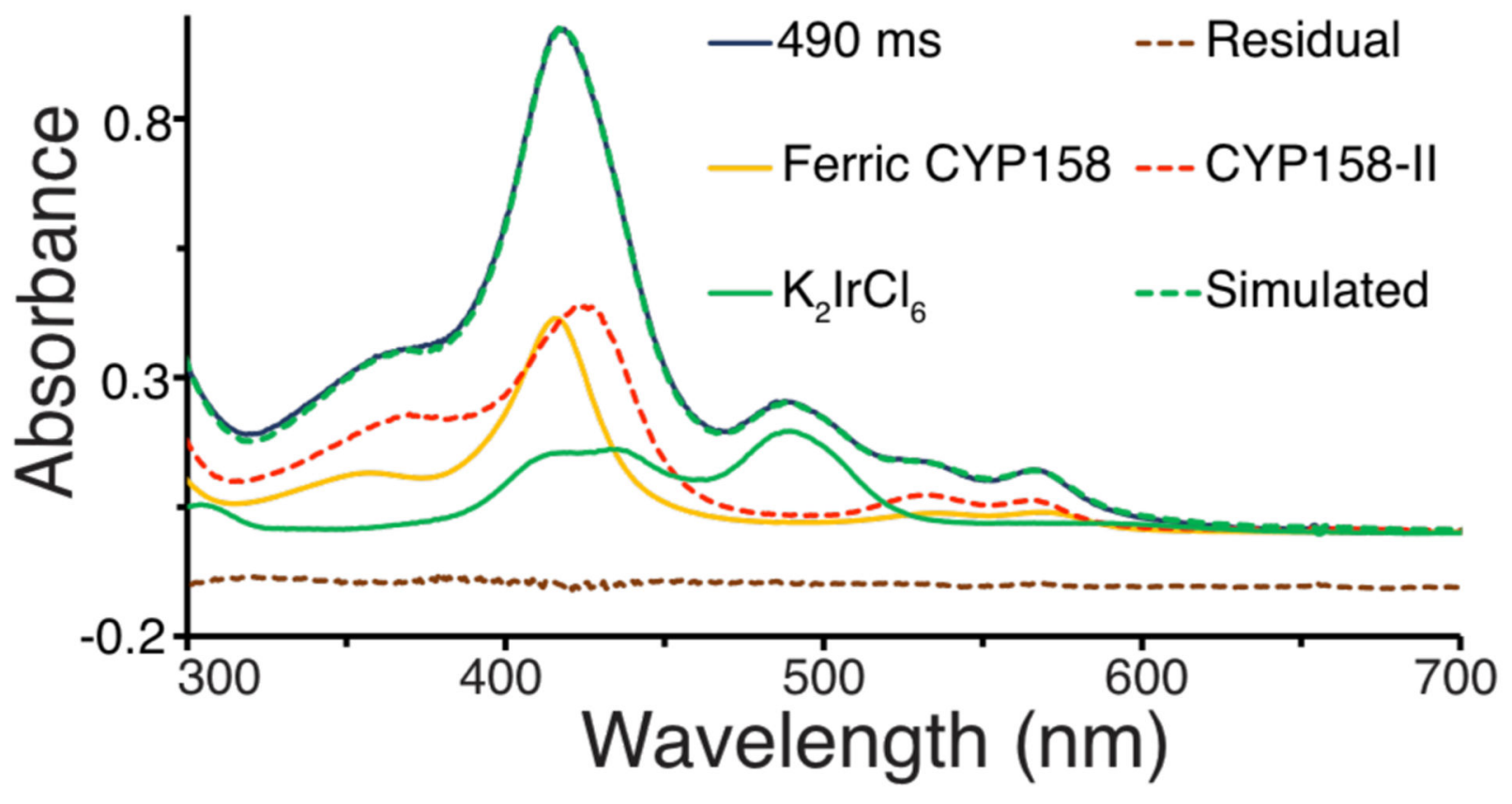

Figure 3.

Experimental and simulated spectra from the pseudo-equilibrium region (490 ms, Fig. 2) using pure spectra of ferric CYP158, CYP158-II, and $\left[\mathrm{Ir}(\mathrm{IV}) \mathrm{Cl}_{6}\right]^{2-}$. The residual shows the difference between the experimental and simulated data. 


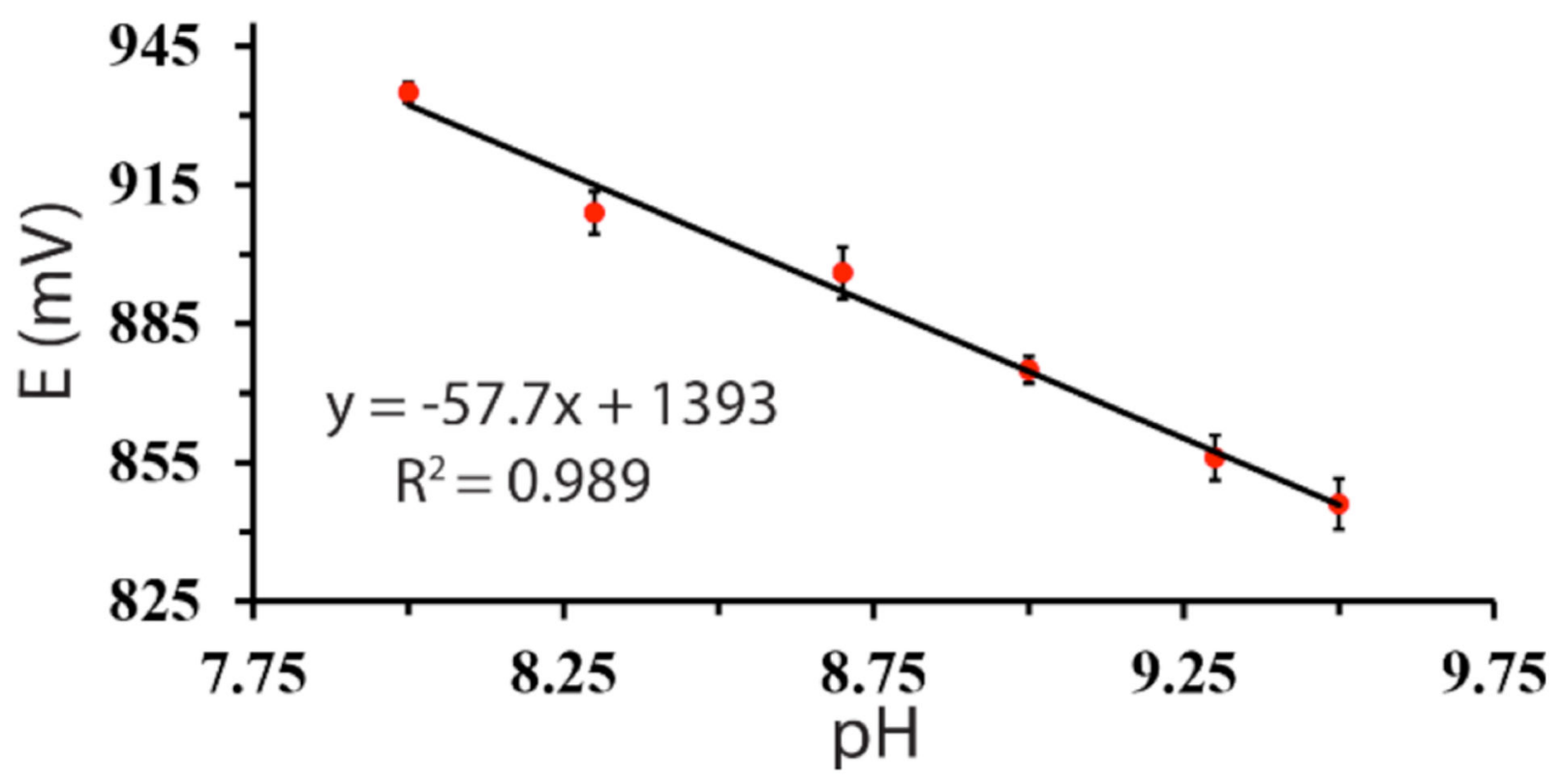

Figure 4.

$\mathrm{E}^{0^{\prime}}$ Comp-II versus $\mathrm{pH}$. 


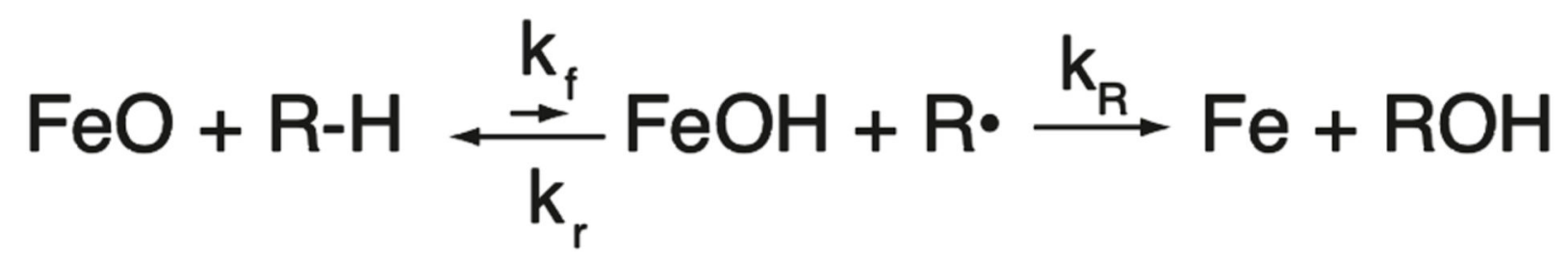

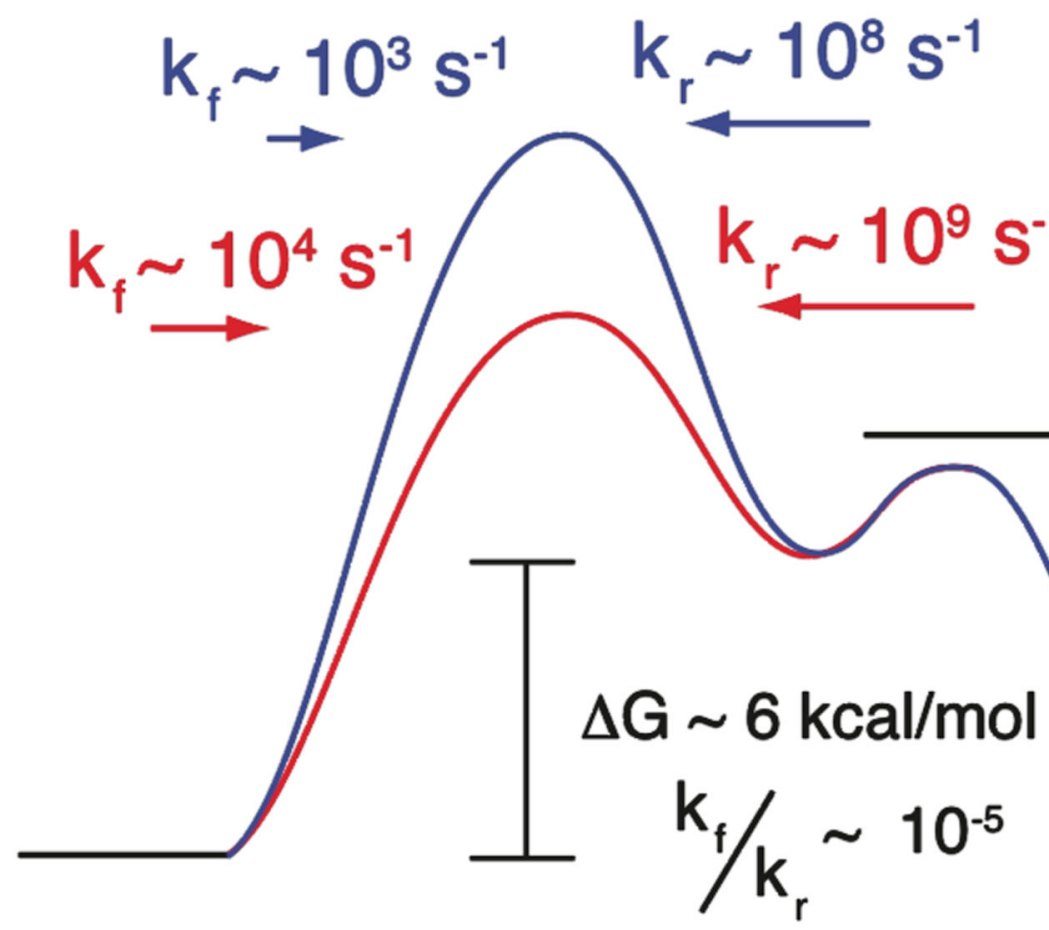

$\Delta \mathrm{G} \sim 6 \mathrm{kcal} / \mathrm{mol}$ $k_{f} / k_{r} \sim 10^{-5}$

\section{$k_{R} \sim 10^{10} \mathrm{~s}^{-1}$}

Figure 5.

General illustration depicting how a rapid rebound step provides a mechanism through which an increase in the forward rate constant for $\mathrm{H}$-atom abstraction creates a more reactive hydroxylating intermediate irrespective of the equilibrium constant for $\mathrm{H}$-atom transfer. $\mathrm{k}_{\mathrm{f}}$ is the forward rate constant for $\mathrm{H}$-atom transfer. $\mathrm{k}_{\mathrm{r}}$ is the reverse rate constant for $\mathrm{H}$-atom transfer. $\mathrm{k}_{\mathrm{R}}$ is the rate constant for rebound. 
Table 1.

$\mathrm{E}^{0^{\prime}}$ Comp-II vs. NHE as a function of $\mathrm{pH}$. The average uncertainty is $\pm 5 \mathrm{mV}$.

\begin{tabular}{ccccccc}
\hline $\mathrm{pH}$ & 8.0 & 8.3 & 8.7 & 9.0 & 9.3 & 9.5 \\
$\mathrm{E}^{0}{ }_{\text {Comp-II }}(\mathrm{mV})$ & 935 & 909 & 896 & 875 & 856 & 846 \\
\hline
\end{tabular}


Table 2.

$\mathrm{E}^{0^{\prime}}$ Comp-II (at pH 8.3 vs. NHE) and [[Ir(III)Cl 6$\left.]^{3-}\right] /[\mathrm{P} 450-\mathrm{II}]$ ratio for the wild type, single mutant, and double mutant CYP158A2. The average uncertainty is $\pm 5 \mathrm{mV}$.

\begin{tabular}{cccc}
\hline & WT & Y352F & Y352F, Y318F \\
\hline $\mathrm{E}^{0^{\prime}} \mathrm{Comp-II}_{1}(\mathrm{mV})$ & 909 & 892 & 879 \\
{$\left[\left[\mathrm{II}(\mathrm{III}) \mathrm{Cl}_{6}\right]^{-3}\right] /[\mathrm{P} 450-\mathrm{II}]$} & $2.1-2.3$ & $1.3-1.5$ & $0.9-1.0$ \\
\hline
\end{tabular}

